\title{
Complement C4 Measurement
}

National Cancer Institute

\section{Source}

National Cancer Institute. Complement C4 Measurement. NCI Thesaurus. Code C80177.

The determination of the amount of complement C4 present in a sample. 